(C) 2013

Ківа О. В., стариий викладач,

Грибініченко В. В., студент

Полтавський національний технічний університет ім. Юрія Кондратюка

\title{
ДОСЛІДЖЕННЯ ВПЛИВУ УЛЬТРАЗВУКОВОЇ ОБРОБКИ ВОДИ НА ПРОРОСТАННЯ НАСІННЯ ЦУКРОВОГО БУРЯКУ
}

\section{Рецензент - доктор технічних наук, професор В. О. Бондар}

\begin{abstract}
Були проведені експериментальні дослідження для визначення впливу попередньої ультразвукової обробки води на схожість та енергію проростання насіння иукрового буряка. Крім того проводились експериментальні дослідження із вивчення впливу тривалості ультразвукової обробки на енергію проростання. Подаються результати проведених експериментальних випробувань та одержані характеристики прочесу проростання насіння в звичайній воді з міського водогону та у водi, яку попередньо піддавали ультразвуковій обробиі, проводиться їх порівняльний аналіз.
\end{abstract}

Ключові слова: насіння, иукровий буряк, схожість, енертія проростання, ультразвукова обробка.

Постановка проблеми. Одним із найбільш ефективних шляхів розв'язання задачі збільшення врожайності $\epsilon$ підвищення якості насіння, поліпшення їх сортності. Особливо гостро це питання стоїть щодо виробництва насіння цукрового буряка, поскільки воно має високу собівартість i, тим не менше, низьку схожість. У зв'язку 3 цим актуальності набуває наразі розробка методів підвищення схожості та енергії проростання насіння.

Аналіз останніх досліджень i публікацій, у яких започатковано розв'язання проблеми. Якість насіння визначається кількома основними характеристиками, до яких відносяться: їх схожість, чистота, енергія проростання, вологість [3]. Схожість - це кількість насінин, що проросли впродовж певного терміну за оптимальних умов. Енергія проростання - це дружність появи паростків за період, менший від необхідного для визначення схожості. 3 метою підвищення схожості насіння використовують радіоактивне опромінення, лазерне опромінення, ультрафіолетове опромінення, теплову обробку, витримку в електростатичному (сталому або змінному) полі, обробку магнітним полем (сталим, змінним, біжучим) [2].

Жоден із вказаних методів, незважаючи на досить позитивні лабораторні випробовування, на жаль, широко не використовується у сільського- сподарському виробництві [5].

Крім того, всі ці методи пов'язані з впливом безпосередньо на насіння. Загальновідомо, що й вода, яка ініціює процес проростання, значною мірою впливає на нього [1]. Наприклад, у дистильованій, водопровідній, дощовій воді ці процеси відбуваються по-різному. На думку авторів, попередня ультразвукова обробка води має впливати також і на процес проростання насіння.

Мета - дослідження впливу ультразвукової обробки води на проростання насіння цукрового буряка.

Завдання дослідження:

1) встановити вплив ультразвукової обробки води на енергію схожості та схожість насіння цукрового буряка;

2) виявити, чи впливає на досліджувані параметри тривалість ультразвукової обробки.

Методи дослідження. Для дослідження впливу ультразвукової обробки води на процес проростання насіння цукрового буряка керамічну тарілку вистеляли тканиною, змоченою водою, яку попередньо піддавали ультразвуковій обробці. В якості джерела коливань частотою $100 \pm 6$ кГц використовували пристрій УСУ 0707 «Retona». На вологу тканину викладали 200 однакових за розміром насінин цукрового буряка, накривали насіння такою ж вологою тканиною, після чого закривали перевернутою тарілкою й залишали на проростання за температури 18-20 ${ }^{\circ} \mathrm{C}$. На 5-й та 10-й день перераховували кількість пророслих насінин. Одночасно з такою ж кількістю насінин проводили досліди на тканині, зволоженій звичайною водою 3 міського водогону.

Результати досліджень. Відомо, що важливим ефектом в ультразвуковому полі $\epsilon$ кавітація - виникнення у рідині пульсуючих пухирців, заповнених парою, газом або їх сумішшю. Складний рух пухирців, їх сплескування, злиття один з одним та ін. породжують в рідині імпульси стиснення (мікроударні хвилі) та мікропотоки, викликають локальне нагрівання середовища, іонізацію. 
СІЛЬСЬКЕ ГОСПОДАРСТВО. РОСЛИННИЦТВО

Вилив ультразвукової обробки води на процес проростання насіння цукрового буряка

\begin{tabular}{|l|c|c|c|c|c|}
\hline \multicolumn{1}{|c|}{$\begin{array}{c}\text { Варіант } \\
\text { обробки води }\end{array}$} & $\begin{array}{c}\text { Кількість } \\
\text { насінин на } \\
\text { проростанні }\end{array}$ & $\begin{array}{c}\text { Середня } \\
\text { кількість проро- } \\
\text { слих насінин } \\
\text { на 5-й день }\end{array}$ & $\begin{array}{c}\text { Середня } \\
\text { кількість проро- } \\
\text { слих насінин } \\
\text { на 10-й день }\end{array}$ & $\begin{array}{c}\text { Енергія } \\
\text { проростання }\end{array}$ & $\begin{array}{c}\text { Схожість } \\
\text { насіння }\end{array}$ \\
\hline Необроблена & 200 & 84,8 & 166,6 & $42,4 \%$ & 83,3 \\
\hline $\begin{array}{l}\text { Обробка } \\
10 \text { хвилин }\end{array}$ & 200 & 125,4 & 168,4 & $64,7 \%$ & 84,2 \\
\hline $\begin{array}{l}\text { Обробка } \\
20 \text { хвилин }\end{array}$ & 200 & 134,2 & 167,8 & $67,1 \%$ & 83,9 \\
\hline $\begin{array}{l}\text { Обробка } \\
\text { 30 хвилин }\end{array}$ & 200 & 133,4 & 168,2 & $66,7 \%$ & 84,1 \\
\hline
\end{tabular}

Ці ефекти впливають на речовину: відбувається руйнування твердих часток, що знаходяться в рідині (кавітаційна ерозія), ініціюються або прискорюються різноманітні фізичні та хімічні процеси [4]. Аналіз впливу ультразвукової обробки води на процес проростання насіння цукрового буряка подано в таблиці.

3 даних таблиці видно, що:

- попередня ультразвукова обробка води практично не впливає на схожість насіння цукрового

\section{БІБЛІОГРАФІЯ}

1. Кисловский Л. Д. Роль воды в лабильности поверхностных структур. - М. : ВИНИТИ, 1982. $-148 \mathrm{c}$.

2. Крылов А. В. Влияние магнитного поля на биологические объекты. - М. : Наука, 1986. -158 с.

3. ДСТУ 4138-2002. Насіння сільськогосподарських культур. Методи визначання якості. - К. : Держспоживстандарт України, 2003. - 173 с. буряка;

- ультразвукова обробка значною мірою підвищує енергію проростання насіння;

- вплив практично не залежить від тривалості цієї обробки.

Висновок. Отже, зміна властивостей води за попередньої ультразвукової обробки дає можливість у цілому покращити якість насіння цукрового буряка за рахунок підвищення енергії проростання.

4. Федоткин И. М., Гульй И. С. Кавитация, кавитационная техника и технология, их использование в промышленности (теория, расчеты и конструкции кавитационных аппаратов). Ч. 1. - К. : Полиграфкнига, 1997. - 940 с.

5. Ходурський В. С., Ківа О. В. Дослідження та розробка пристрою для передпосівної обробки насіння цукрового буряка // Вісник Полтавської державної аграрної академії. - №4, 2010. - C. 176-178. 